\title{
Spatial Distribution of Euschistus heros (Hemiptera: Pentatomidae) in Cotton (Gossypium hirsutum Linnaeus)
}

\author{
ANDERSON C. WEBER ${ }^{1}$, PAULO E. DEGRANDE ${ }^{1}$, ELLEN P. DE SOUZA ${ }^{2}$, \\ ROSALIA AZAMBUJA ${ }^{2}$ and MARCOS G. FERNANDES ${ }^{2}$ \\ ${ }^{1}$ Universidade Federal da Grande Dourados, Faculdade de Ciências Agrárias, Rodovia Dourados/ \\ Itahum, Km 12, Cidade Universitária, Caixa Postal 364, 79804-970 Dourados, MS, Brazil \\ ${ }^{2}$ Universidade Federal da Grande Dourados, Faculdade de Ciências Biológicas e Ambientais, Rodovia \\ Dourados/Itahum, Km 12, Cidade Universitária, Caixa Postal 364, 79804-970 Dourados, MS, Brazil
}

Manuscript received on May 24, 2017; accepted for publication on March 26, 2018

\begin{abstract}
Recently, the Neotropical brown stink bug, Euschistus heros (Pentatomidae: Hemiptera), has been detected in cotton in the Brazilian Cerrado. Several reliable surveys have been conducted on the spatial distribution of stink bugs in soybean; however, few studies have examined the behavior of this insect in cotton in Brazil. Thus, this study examined the spatial distribution of E. heros in cotton using aggregation indices based on the variance-to-mean ratio, Morisita index, exponent $\mathrm{k}$, Poisson and negative binomial distributions. Inverse Distance Weighting interpolation maps were also used to represent insect density. The study was conducted in a 1.1 hectare experimental cotton field in which 64 equally-sized plots were sampled on a weekly basis. Our findings revealed that stink bugs presented an aggregate distribution in 2 sampling weeks based on aggregation indices, and this pattern was best described by a negative binomial distribution. Maps showing the density of pests can be an important tool for sampling pests in crops and control measures in early stages of infestation, when there is an edge effect on the distribution of $E$. heros, can be an efficient strategy in cotton.
\end{abstract}

Key words: Aggregation Indices, Dispersion, GIS, IPM, Negative Binomial.

\section{INTRODUCTION}

The Neotropical brown stink bug, Euschistus heros (Hemiptera: Pentatomidae) (F.), usually occurs in the cotton and is becoming an economically important pest for Brazilian cotton growers (Soria et al. 2009). In Brazil, E. heros is the species with the highest incidence in cotton fields (Soria et al. 2009). Most stink bugs attack cotton fields

Correspondence to: Ellen Patrícia de Souza

E-mail: ellen_psouza@hotmail.com during the development of cotton bolls, causing immaturity, stained lint, general loss of fiber quality, and reduced yield (Reay-Jones et al. 2009). Stink bugs feeding on cotton can also result in indirect damage due to the transmission of pathogens, such as the bacterium Pantoea agglomerans, which causes cotton boll rot (Medrano et al. 2007).

The high incidence of E. heros is caused by the simultaneous sowing of soybean and cotton, in which stink bugs migrate from the former to the latter. This occurs due to an inefficient pest control 
in soybean, high density of insects, and dispersion of the pest population from one area to another in search of food, and the attacks coincide with the formation of bolls, the most critical stage in the development of cotton (Soria et al. 2010, 2009).

Integrated pest management depends on an efficient sampling method that is essential when deciding to perform an effective pest control. Spatial distribution models can identify when a species has a regular, random, or aggregated spatial distribution in field, in which probabilistic models of Poisson, positive and negative binomial distributions are respectively used to describe the types of pattern of a pest (Young and Young 1998).

The use of surface maps increases the understanding of the spatial interactions of an organism within a given area. These maps of geospatial variability are very accurate for Integrated Pest Management (Fleisher et al. 1999). The interpolation of the data from the sampling area consists of generating data from non-sampled sites, with the construction of surface models or surface maps. Among the methods of interpolation, the Inverse Distance Weighting (IDW) can be used to assist in evaluating the spatial distribution of stink bugs in cotton growing areas (Reay-Jones et al. 2010). Therefore, we investigated the spatial distribution pattern of the Neotropical brown stink bug, E. heros, in cotton to develop management strategies for this pest.

\section{MATERIALS AND METHODS}

The study was carried out at the Experimental Farm of Agricultural Sciences of the Federal University of Grande Dourados (Fazenda Experimental de Ciências Agrárias da Universidade Federal da Grande Dourados - FAECA UFGD), located in the municipality of Dourados (MS), latitude $22^{\circ} 14^{\prime} 07^{\prime \prime}$ $\mathrm{S}$ and longitude $54^{\circ} 59^{\prime} 17^{\prime}$ ' $\mathrm{W}$. The area consisted of 1.1 hectare experimental field cultivated with cotton variety FiberMax ${ }^{\circledR}$ 910, and corn planted around the edges to isolate it from stink bugs present in surrounding soybean fields in different infestation levels, and appropriate management practices were carried out when needed.

For sampling purposes, the experimental field was divided into 64 equally-sized $(13 \times 13 \mathrm{~m})$ plots. In each plot, two whole cotton plants in the central lines were examined weekly, during the entire growing season, starting at 7 DAE (days after emergence) up to $118 \mathrm{DAE}$, and counts of adults of $E$. heros were obtained for each plot directly in the plant

The numbers of adults of stink bugs obtained in cotton in each plots were used to determine the spatial distribution of the population. Stink bugs were found in nine of 14 sampling dates, , between $64 \mathrm{DAE}$ and $118 \mathrm{DAE}$, which were used to calculate the mean, variance, and aggregation indices. Sampling dates in which the insects did not occur (from 7 DAE to 57 DAE) were not included. Dispersion indices were obtained to determine the type of spatial distribution of the pest in the field. Also, the Poisson and negative binomial distributions were fitted to the data to test observed and expected frequencies.

\section{DISPERSION INDICES}

The variance/mean ratio $\left(I=s^{2} / m\right)$ measures the deviation of an arrangement from randomness. Values equal to zero indicate a random spatial pattern; values less than one indicate a regular or uniform spatial distribution; and values significantly greater than one indicate contagious or clustered spatial arrangement (Davis 1994). With the data obtained in each plot, the chi-square test was used to analyze randomness.

The Morisita's index $I_{s}$ (Morisita 1962) is independent from the sample mean and the total number of individuals. Values equal to one indicate a random pattern, while values greater than one indicate an aggregated arrangement. Values less than 
one indicate a uniform or regular distribution. The chi-square test is used to reject randomness when the calculated $\mathrm{X}^{2}$ is greater than the table value.

The exponent $k$ of the negative binomial distribution can be determined with the Method of Moments (MM) or Maximum Likelihood Estimation (MLE) (Young and Young 1998). In the present study, MM was used to estimate this exponent, which indicates aggregation when $k>$ 0 and $k<8$, where $k<0>8$ indicates a random distribution.

\section{FREQUENCY DISTRIBUTION}

The Poisson and negative binomial distributions were used as models for the population samples. The Poisson distribution indicates randomness and is characterized by a variance equal to the mean, using only the sample mean as the parameter of evaluation. On the other hand, the negative binomial distribution indicates spatial aggregation and is characterized by a variance greater than average, using as parameters the sample mean and the exponent $k$ (Young and Young 1998).

Therefore, the theoretical frequency distributions used to evaluate the spatial distribution of $E$. heros in the cotton field were fitted to the data with the chi-square goodness-of-fit test $\left(X^{2}\right)$, which compares observed and expected frequencies (Young and Young 1998). The observed frequencies of the data collected were assigned into classes; each class represented the numerical value for the observed and expected frequency of $E$. heros of the sampling. The level of significance was set at $5 \%$.

\section{SPATIAL ANALYSIS WITH THE GEOGRAPHIC INFORMATION SYSTEM}

For the representation of the statistical models, surface maps of the site were obtained with Inverse Distance Weighted (IDW) interpolation, using the Software QGIS ${ }^{\circledR}$ (www.qgis.org). The maps described the population density of stink bugs in the experimental field.

\section{RESULTS}

The number of adult insects per plot recorded weekly was highly variable and the observed frequency of stink bugs was low at 64 DAE and 70 DAE. The first occurrence of E. heros was observed at 64 DAE when cotton plants were in the reproductive development stage, with only two classes in the beginning of the study and reaching up to five classes in the last sampling dates.

In the beginning of this study, only one insect was observed per sample plot. Class zero represents the frequency of 0 s and class one includes the frequency of 1s (Fig. 1). In the first and second sampling dates, insects were found in the plots on the edge of the cotton field (Fig. 2), indicating the arrival of the pest from adjacent areas planted with corn.

Based on the variance/mean ratio, the level of aggregation of E. heros adults was low in the cotton field. Thus, values were statistically lower than the threshold, except for the samples at 106 DAE and 118 DAE, showing that stink bugs were aggregated only in these two dates. In all others, a random distribution of insects was observed in cotton plots (Table I).

The Morisita index was statistically similar to the variance/mean ratio (Table I), indicating that stink bugs were aggregated in only in the samples at $106 \mathrm{DAE}$ and $118 \mathrm{DAE}$, tending to a random distribution.

The results of the exponent $k$ of the negative binomial distribution, however, suggested that stink bugs were more aggregated in the cotton field. The exponent $k$ obtained with the method of moments (MM) was between 0 and 8 , suggesting an aggregated distribution in most sampling dates $(84,90,96,106,111$ and 118 DAE) in the field (Table I). These values are similar to some of those obtained for the Morisita index and the variance/ mean ratio. 


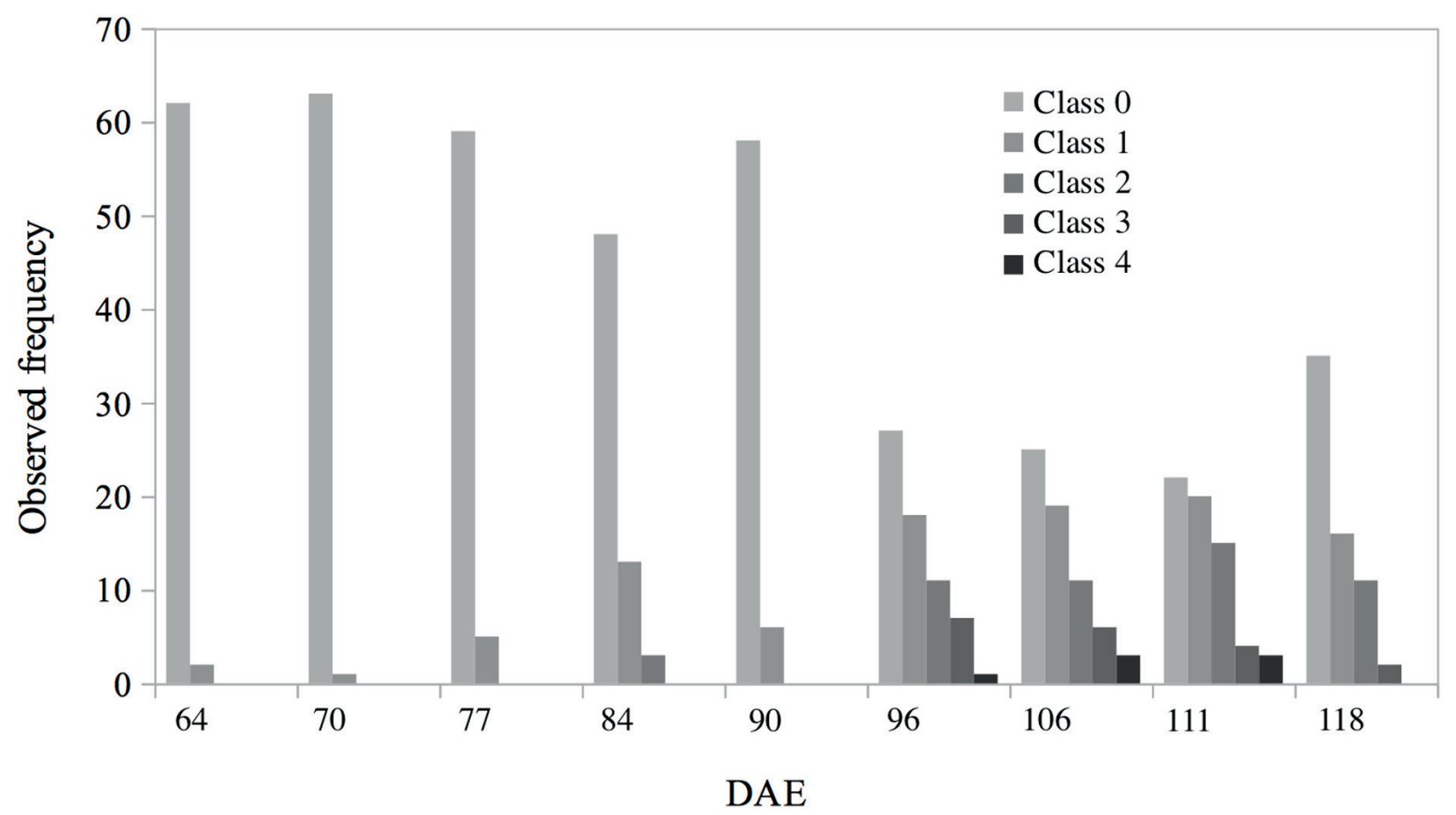

Figure 1 - Observed frequency of E. heros in nine cotton sampling dates between 64 and 118 days after emergence (DAE), and grayscale color representing each class. Dourados - MS, Brazil.

For the chi-square goodness-of-fit test, the value obtained with $\mathrm{N}-1$ degrees of freedom and significance level of 5\% was 82,529. Thus, all $X^{2}$ values calculated lower than the table value were rejected, and did not reach the threshold to be considered aggregated.

In the present study, the negative binomial distribution best described the frequency of stink bugs, although there is also adjustment for the Poisson distribution, the Chi-square values of the Negative Binomial Distribution are smaller in relation to those of Poisson; this indicates a better fit for Negative Binomial. Also, by the surface maps (Figure 2) it is possible to observe an aggregate distribution of the population. The number of classes of frequency of stink bugs was insufficient until 90 DAE (Table II) . This distribution is characterized by a variance greater than the mean $\left(s^{2}>\bar{x}\right)$ and thus, the negative binomial distribution significantly fitted the data, reflecting the aggregation pattern of the brown stink bug in cotton. The samples of $E$. heros analyzed with chisquare test were not significant.

The data obtained for the Neotropical brown stink bug were also tested to Poisson distribution, however, there were not good adjustment because it is characterized by a variance equal to the mean.

The negative binomial and Poisson distributions were sufficient to identify the best spatial pattern to describe the Neotropical brown stink bug in cotton. Thus, the results suggest that E. heros adults were aggregated in the cotton field, and is best described by the negative binomial distribution, since variance values were higher than the mean, besides the negative binomial values were lower than those obtained for the Poisson distribution, approaching zero.

\section{SPATIAL ANALYSIS WITH GEOGRAPHIC INFORMATION SYSTEM}

The surface maps made for each sampling revealed the areas with higher density of stink 
TABLE I

Dispersion indices of the spatial distribution of the stink bug E. heros in cotton, Dourados - MS, Brazil.

\begin{tabular}{ccccccccccc}
\hline $\begin{array}{c}\text { Samples } \\
\text { (DAE) }\end{array}$ & $\mathbf{6 4}$ & $\mathbf{7 0}$ & $\mathbf{7 7}$ & $\mathbf{8 4}$ & $\mathbf{9 0}$ & $\mathbf{9 6}$ & $\mathbf{1 0 6}$ & $\mathbf{1 1 1}$ & $\mathbf{1 1 8}$ \\
\hline $\mathrm{M}$ & 0.031 & 0.016 & 0.078 & 0.313 & 0.109 & 1.031 & 1.125 & 1.188 & 0.719 \\
$S^{2}$ & 0.031 & 0.016 & 0.073 & 0.377 & 0.131 & 1.301 & 1.476 & 1.456 & 0.967 \\
$I$ & $0.984^{a l}$ & $1.000^{a l}$ & $0.937^{a l}$ & $1.206^{a l}$ & $1.195^{a l}$ & $1.261^{a l}$ & $1.312^{a g}$ & $1.226^{a l}$ & $1.346^{a g}$ \\
$I_{\delta}$ & - & - & - & $1.684^{a l}$ & $3.048^{a l}$ & $1.253^{a l}$ & $1.277^{a g}$ & $1.190^{a l}$ & $1.484^{a g}$ \\
$K$ & $1.969^{a g}$ & - & $-1.230^{a l}$ & $1.514^{a g}$ & $0.561^{a g}$ & $3.948^{a g}$ & $3.604^{a g}$ & $5.245^{a g}$ & $2.079^{a g}$ \\
$X^{2}$ & 62.00 & - & 59.00 & 76.00 & 75.29 & 79.45 & 82.67 & 77.26 & 84.78 \\
\hline
\end{tabular}

$\mathrm{DAE}=$ days after emergence; $\mathrm{M}=$ mean; $S^{2}=$ variance; $I=$ variance/mean ratio; $I_{\delta}=$ Morisita index; $k=$ exponent $\mathrm{k} ; X^{2}=$ calculated chi-square; ${ }^{a g}=$ Aggregated; ${ }^{a l}=$ Random.

bugs. The initial pattern of insects sampled showed the colonization of cotton field edges near corn, indicating that E. heros dispersed from corn to cotton. (Fig. 2).

Inverse Distance Weighting (IDW) interpolations indicated the areas of the first occurrences of stink bugs in the plots. The initial pattern of the insects was on the edge of the cotton field and at 77 DAE, stink bugs was found within the field. The population peaked at $96 \mathrm{DAE}$ (Fig. 2). Thus, a control method focused on the edges of the field could be effective in early stages of $E$. heros infestations. However, once stink bugs are settled in the area, the entire field needs to be treated.

The maps showed the areas with the highest population densities of stink bugs, which were aggregated based on the variance/mean ratio and Morisita index. These parameters can be compared with 96 to 118 DAE interpolated maps representing the data described by the Negative Binomial Distribution (Fig. 2).

\section{DISCUSSION}

After the third week, a significant increase in the $E$. heros population was observed in the area, which fluctuated constantly during the sampling weeks in the study area (Fig. 1). This variation within the field can be associated with the movement of insects searching for food. According to Azambuja et al.
(2013), E. heros attacks cotton due to the shortage of other foods, becoming an alternative pest in the crop, although Edessa meditabunda also normally develops on this crop (Azambuja et al. 2015).

Stink bugs movement between closely associated host plants throughout the growing season may be a response to a decrease in the availability of their current host plants (Jones and Sullivan 1982, Velasco and Walter 1992, Ehler 2000, Tillman and Cottrell 2016a). Crop-to-crop dispersal of stink bug species has been reported for many cropping systems (Tillman et al. 2009, Reay-Jones et al. 2010, Reeves et al. 2010, Tillman 2011, Reisig et al. 2013). When stink bugs disperse from one crop to another, they aggregate at field borders. Therefore, there is a pronounced edge effect observed in the distribution of stink bugs as they colonize a new crop (Zalom et al. 1997, Espino et al. 2008, Reay-Jones 2010, Reay-Jones et al. 2010, Reeves et al. 2010; Olson et al. 2012, Reisig et al. 2013, Tillman et al. 2014).

Regarding the spatial distribution of phytophagous stink bugs, Todd and Herzog (1980) reported an aggregated pattern for the green stink bug Nezara viridula in southeastern United States. In addition to dietary habits, Tillman and Cottrell (2016b) reported that pheromones, such as aggregation pheromones, can influence the mobility of stink bugs and consequently their spatial 

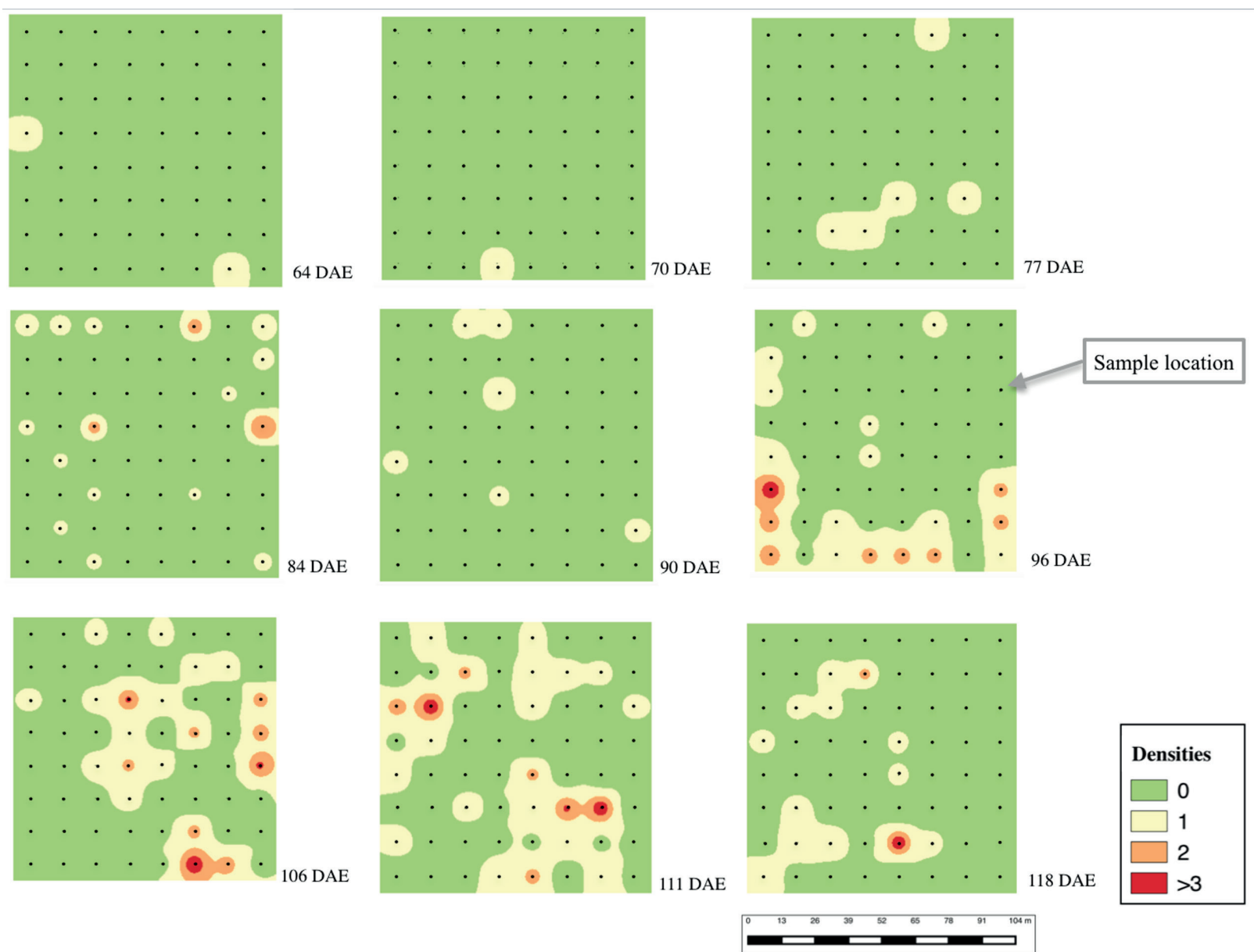

Figure 2 - Surface maps constructed based on Inverse Distance (IDW) interpolation showing spatial distribution of stink bug density in cotton in nine sampling dates between 64 and 118 days after emergence (DAE). Low density is represented in green while red indicates high density of $E$. heros.

distribution. Thus the movement of insects to the cotton field can occur as a result of the presence of neighboring host plants and the availability of a new food source.

Our findings indicate an aggregate distribution pattern of E. heros in cotton, corroborating other studies and it is best described by the negative binomial distribution (Santos et al. 2004, Souza 2012). Therefore, stink bugs can move into cotton by the edges of the field and cluster in different places at each sampling date, possibly as a result of the phenological stage of cotton plants and the search for food (Reisig et al. 2015).

Considering all sampling dates, infestation levels were low until $84 \mathrm{DAE}$ and the first incidence of insects were observed in plots on the edges of the field indicating a classic edge effect. Soria et al. (2010) reported that the presence of E. heros depends on the phenological stage of cotton plants and that in most cases, stink bugs migrate to cotton from surrounding crops. Pilkay et al. (2015) also found a higher incidence of stink bugs in crops cultivated near areas planted with soybeans.

Stink bugs of the Pentatomidae family, such as $N$. viridula and E. servus, also have been reported colonizing agricultural landscapes from the edges of the crop (Edge Effect) and then dispersing in the field or to other crops, in which the height of the plant can influence its dispersion suggesting that larger plants could function as a natural barrier in 
TABLE II

Chi-square goodness-of-fit test of the observed and expected frequencies of $E$. heros per plot and the Poisson and negative binomial distributions. Dourados - MS, Brazil.

\begin{tabular}{cccccc}
\hline & \multicolumn{2}{c}{ Samples } & \multicolumn{2}{c}{ Negative binomial } & \multicolumn{2}{c}{ Poisson } \\
\hline $1^{\text {st }}$ & DAE & $\mathbf{X}^{\mathbf{2}}$ & $\mathbf{D F}$ - 3 & $\mathbf{X}^{2}$ & DF -2 \\
$2^{\text {nd }}$ & 64 & $i$ & - & $i$ & - \\
$3^{\text {rd }}$ & 70 & $i$ & - & $i$ & - \\
$4^{\text {th }}$ & 77 & $i$ & - & $i$ & - \\
$5^{\text {th }}$ & 84 & $i$ & - & $0.2933^{\text {NS }}$ & 1 \\
$6^{\text {th }}$ & 90 & $i$ & - & $i$ & - \\
$7^{\text {th }}$ & 96 & $2.7855^{\text {NS }}$ & 2 & $4.1782^{\text {NS }}$ & 3 \\
$8^{\text {th }}$ & 106 & $0.3651^{\mathrm{NS}}$ & 2 & $3.1180^{\text {NS }}$ & 3 \\
$9^{\text {th }}$ & 111 & $1.0858^{\mathrm{NS}}$ & 2 & $1.7456^{\mathrm{NS}}$ & 3 \\
\hline
\end{tabular}

$\mathrm{DAE}=$ days after emergence; $\mathrm{X}^{2}=$ calculated chi-square; $\mathrm{DF}=$ degrees of freedom; ${ }^{\mathrm{NS}}=$ Not significant at the $5 \%$ probability level; $i=$ insufficient number of classes.

the dispersal of bed bugs, as observed by Tillman (2014). Further studies are needed on plants as barriers as an alternative to hinder the dispersion and distribution of stink bugs .

\section{SPATIAL ANALYSIS WITH GEOGRAPHIC INFORMATION SYSTEM}

Several studies have been carried out to determine the spatial distribution of insects in cash crops. The mean and variance are used to determine the distribution pattern of an insect but do not take into account the location of the pest in the area. ReayJones et al. (2010) demonstrated that pentatomids have an aggregate pattern in cotton fields, using statistical methods and mapping based on Inverse Distance Weighting (IDW) interpolation. Thus, surface maps may be more effective to identify the location of insects in the study area and to show the spatial distribution of the insect during its establishment in the field.

Based on studies conducted in the United States on pentatomids, Reay-Jones et al. (2010) reported that mapping stink bug density and damage to cotton bolls are effective ways to describe both variables.
Moradi-Vajargah et al. (2011) suggested the Taylor Regression model to assist the identification of distribution patterns of pests.

With the use of surface maps, the areas with the highest densities of stink bugs can be identified. The areas with greater damage to cotton plants caused by the insects may be different than those with higher densities, thus suggesting the need to assess cotton boll damage (Pulakkatu-Thodi et al. 2014).

\section{CONCLUSIONS}

The distribution of brown stink bug was aggregated based on the variance/mean ratio, the Morisita index, and the exponent $k$ of the negative binomial distribution.

The negative binomial distribution was able to describe the aggregation of E. heros and our findings may be useful in future sampling plans in cotton.

Sampling maps can be a useful tool to monitor agricultural pests, to identify their initial spatial location, and to determine their distribution within the cotton field. 


\section{REFERENCES}

AZAMBUJA R, DEGRANDE PE AND PEREIRA FF. 2013. Comparative Biology of Euschistus heros (F.) (Hemiptera: Pentatomidae) Feeding on Cotton and Soybean Reproductive Structures. Neotrop Entomol 42: 359-365.

AZAMBUJA R, DEGRANDE PE, SOUZA EP, PEREIRA FF AND PASTORI PL. 2015. Reprodução de Edessa meditabunda (Hemiptera: Pentatomidae) em algodoeiro. Acta Biol Colomb 20: 203-208.

DAVIS PM. 1994. Statistics for Describing Populations. In: Pedigo LP and Buntin GD, Handbook of Sampling Methods for Arthropods in Agriculture. Florida: CRC Press, p. 33-53.

EHLER LE. 2000. Farmscape Ecology of Stink Bugs in Northern California; Entomological Society of America: Lanham, MD, USA, p. 59.

ESPINO L, WAY MO AND WILSON LT. 2008. Sequential sampling plans for sweep net and visual sampling of Oebalus pugnax in rice. Southwest. Entomol 33: 53-64.

FLEISHER SJ, BLOM PE AND WEISZ R. 1999. Sampling in Precision IPM: When the objective is a map. Phytopathology 89: 1112-1118.

JONES WA AND SULLIVAN MJ. 1982. Role of host plants in population dynamics of stink bug pests of Soybean in South Carolina. Environ Entomol 11: 867-875.

MEDRANO EG, ESQUIVEL JF AND BELL AA. 2007. Transmission of cotton seed and boll rotting bacteria by the southern green stink bug (Nezara viridula L.). J Appl Microbiol 103: 436-444.

MORADI-VAJARGAH M, GOLIZADEH A, RAFIEEDASTJERDI H, ZALUCKI M, HASSANPOUR M AND NASERI B. 2011. Population Density and Spatial Distribution Pattern of Hypera postica (Coleoptera: Curculionidae) in Ardabil, Iran. Not Bot Horti Agrobo 9: 42-28.

MORISITA M. 1962. $I_{\delta}$-index, a measure of dispersion of individuals. Res Popul Eco (Kyoto) 4: 1-7.

OLSON DM, RUBERSON JR AND ANDOW DA. 2012. Effects on stink bugs of field edges adjacent to woodland. Entomol Exp Appl 156: 94-98.

PILKAY GL, REAY-JONES FP, TOEWS MD, GREENE JK AND BRIDGES WC. 2015. Spatial and temporal dynamics of stink bugs in southeastern farmscapes. J Insect Sci 5: 1-13.

PULAKKATU-THODI I, REISIG DD, GREENE JK, REAYJONES FPF AND TOEWS MD. 2014. Within-Field Spatial Distribution of Stink Bug (Hemiptera: Pentatomidae)Induced Boll Injury in Commercial Cotton Fields of the Southeastern United States. Environ Entomol 43: 744-752.

REAY-JONES FPF. 2010. Spatial and temporal patterns of stink bugs (Hemiptera: Pentatomidae) in wheat. Environ Entomol 39: 944-955.
REAY-JONES FPF, TOEWS MD, GREENE JK AND REEVES RB. 2009. Sampling stink bugs (Hemiptera: Pentatomidae) for population estimation and pest management in southeastern cotton production. J Econ Entomol 102: 2360-2370.

REAY-JONES FPF, TOEWS MD, GREENE JK AND REEVES RB. 2010. Spatial Dynamics of Stink (Hemiptera: Pentatomidae) and Associated Boll Injury in Southeastern Cotton Fields. Environ Entomol 39: 956-969.

REEVES RB, GREENE JK, REAY-JONES FPF, TOEWS MD AND GERARD PD. 2010. Effects of adjacent habitat on populations of stink bugs (Heteroptera: Pentatomidae) in cotton as part of a variable agricultural landscape in South Carolina. Environ Entomol 39: 1420-1427.

REISIG DD, REAY-JONES FPF AND MEIJER AD. 2015. Aggregation and association of NDVI, boll injury, and stink bugs in North Caroline cotton. J Insect Sci 15: 1-4.

REISIG DD, ROE M AND DHAMMI A. 2013. Dispersal pattern and dispersion of adults and nymph stink bugs (Hemiptera: Pentatomidae) in wheat and corn. Environ Entomol 42: 1184-1192.

SANTOS RSS, REDAELLI LR, DIEFENBACH LMG, ROMANOWSKI HP, PRANDO HF AND ANTOCHEVIS RC. 2004. Distribuição espacial de Oebalus poecilus (Dallas, 1851) (Hemiptera: Pentatomidae) durante a hibernação. Entomotropica 19: 91-100.

SORIA MF, DEGRANDE PE AND PANIZZI AR. 2010. Invasão inusitada. Cultivar: Grandes Culturas 131(4): 1820.

SORIA MF, THOMAZONI D, MARTINS RR AND DEGRANDE PE. 2009. Stink bugs incidence on Bt cotton in Brazil. In: Beltwide Cotton Conferences, 2009, San Antonio, Texas, EUA. Beltwide Cotton Conferences Proceedings 8: 13-819.

SOUZA LA. 2012. Distribuição espacial e plano de amostragem sequencial para Euschistus heros (Fabricius, 1794) (Heteroptera: Pentatomidae) na cultura da soja convencional e transgênica [Dissertação]. Faculdade de Ciências Agrárias e Veterinárias, Universidade Estadual Paulista, Jaboticabal. (Unpublished).

TILLMAN PG. 2011. Influence of corn on stink bugs (Heteroptera: Pentatomidae) in subsequent crops. Environ Entomol 40: 1159.

TILLMAN PG. 2014. Physical barriers for suppression of movement of adult stink bugs into cotton. J Pest Sci 87: 419-427.

TILLMAN PG AND COTTRELL TE. 2016a. Density and egg parasitism of stink bugs (Hemiptera: Pentatomidae) in elderberry and dispersal into crops. J Insect Sci 16: 1-14.

TILLMAN PG AND COTTRELL TE. 2016b. Attraction of Stink Bug (Hemiptera: Pentatomidae) Nymphs to Euschistus Aggregation Pheromone in the Field. Florida Entomol 99: 678-682. 
TILLMAN PG, COTTRELL TE, MIZELL RFIII AND KRAMER E. 2014. Effect of field edges on dispersal and distribution of colonizing stink bugs across farmscapes of the Southeast US. Bull Entomol Res 104: 56-64.

TILLMAN PG, NORTHFIELD TD, MIZELL R AND RIDDLE RC. 2009. Spatiotemporal patterns and dispersal of stink bugs (Heteroptera: Pentatomidae) in peanut-cotton farmscapes. Environ Entomol 38: 1038-1052.

TODD JW AND HERZOG DC. 1980. Sampling phytophagous Pentatomidae on soybean. In: Kogan M and Herzog D.C. Sampling methods in soybean entomology, New York: Springer-Verlag, p. 438-478.

VELASCO LRI AND WALTER GH. 1992. Availability of different host plant species and changing abundance of the polyphagous bug Nezara viridula (Hemiptera: Pentatomidae). Environ Entomol 21: 751-759.

YOUNG LJ AND YOUNG JH. 1998. Statistical ecology: a population perspective. Boston: Kluwer Academic Publishers, $565 \mathrm{p}$.

ZALOM FG, SMILANICK JM AND EHLER LE. 1997. Spatial patterns and sampling of stink bugs (Hemiptera: Pentatomidae) in processing tomatoes. In Proceedings of the 1st International Conference on the Processing Tomato, 1st International Symposium on Tropical Tomato Diseases, Recife, Pernambuco, Brazil, 21-22 November 1996; Maciel GA, Lopes GMB, Hayward C, Marino RRL and de A Maranhao EA (Eds), ASHS press: Alexandria, VA, USA, p. 75-79. 